DOI: 10.12731/2658-4034-2020-1-45-49

\title{
О НЕКОТОРЫХ ВОЗМОЖНОСТЯХ ПРИМЕНЕНИЯ ИНТЕРНЕТ ВЕЩЕЙ В ОБРАЗОВАТЕЛЬНОЙ СФЕРЕ
}

\author{
Преображженский А.П. ${ }^{1}$, Чопоров О.Н. ${ }^{2}$
}

${ }^{1}$ Воронежский институт высоких технологий,

г. Воронеж, Российская Федерация

${ }^{2}$ Воронежский государственный технический университет,

г. Воронеж, Российская Федерация

В данной работе проведено рассмотрение возможностей применения технологий Интернет вещей в образовательной сфере. Приведены примеры повышения эффективности подготовки кадров.

Ключевые слова: интернет вещей; обучающийся; методика; технология.

\section{ABOUT SOME POSSIBILITIES OF USING THE INTERNATIONAL OF THINGS IN THE EDUCATIONAL SPHERE}

\section{Preobrazhenskiy A.P. ${ }^{1}$, Choporov O.N. ${ }^{2}$}

${ }^{1}$ Voronezh Institute of High Technologies, Voronezh, Russian Federation ${ }^{2}$ Voronezh State Technical University, Voronezh, Russian Federation

In this paper, we consider the possibilities of using Internet of things technologies in the educational sphere. Examples of increasing the effectiveness of training are given.

Keywords: Internet of things; student; methodology; technology. 


\section{Введение}

Интернет вещей развивается уже более двух десятилетий. Если вначале области его применения были достаточно ограниченными, то впоследствии указанную технологию стали применять в самых разных сферах, в том числе и в образовательной. В данной работе рассматриваются некоторые характеристики Интернета вещей в образовании.

\section{О практических вопросах использования Интернет вещей}

Передача информации в Интернет вещей осуществляется при анализе технологических, технических и физических особенностей. Постепенно современные пользователи переходят от использования стационарных устройств выхода в Интернет к мобильным электронным устройствам, использованию облачных технологий [1].

При этом есть возможности для дистанционного управления различными объектами. Интернет становится интеллектуальным. Возрастает роль людей как промежуточных звеньев в управлении процессами передачи, обработки информации, оценки ее эффективности. Также они осуществляют процессы принятия различных решений [2].

В образовательной сфере специфика Интернета вещей состоит в возникновении новых качественных характеристик большого числа мобильных устройств, непрерывном доступе к данным с возможностями осуществления с ними разных операций, возможностями применения большого числа новых сервисов, использовании технологий комплексирования в ходе процессов связи по телекоммуникациям [3].

Каждый из пользователей имеет возможности для того, чтобы для решения соответствующих классов задач делать выбор по виду мобильных устройств [4].

В дальнейшем, происходит процесс идентификации обучающихся, им передаются на устройства учебные задания.

Есть возможности для сбора всей статистической информации по каждому участнику учебной группы. Задания даются диффе- 
ренцированным образом, при учете подготовки каждого из обучающихся.

С каждым из них тьютор может общаться так, что это не будет отвлекать других студентов.

Преподаватели должны соответствующим образом уметь использовать инструментальные средства внутри умных аудиторий, кроме того, потребуются общепедагогические подходы обучения дисциплин.

Безусловно, педагог должен взвешенно использовать соответствующие устройства и технологии, чтобы не было нарушена личная аура обучающихся.

Сами интеллектуальные устройства рассматриваются в виде определенных вспомогательных компонентов, дающих возможности для поддержки рекомендательных операций.

На обучении происходит фиксация внимания обучающихся, убираются разные отвлекающие факторы.

Вопросы, связанные с оценкой мозговой активности, на настоящий момент еще определяют определенные разногласия среди разных педагогов.

На основе технологий Интернета Вещей в существующих условиях есть возможности для того, чтобы осуществлять эффективную подготовку кадров для промышленных предприятий.

Существуют определенные проблемы на практике, связанные с коммерциализацией ИТ-решений Интернет вещей в образовательных процессах. То есть, современные технологии должны обеспечивать получение дохода. Это обуславливает необходимость в подготовке специалистов, обладающих бизнес-компетенциями [5].

\section{Выводы}

Технологии Интернет вещей в образовательной сфере дают возможности для получения обучающимися знаний более качественным образом. Преподаватели должны разрабатывать соответствующие методики, адаптирующие актуальные образовательные подходы к современным технологиям. 


\section{Список литературы}

1. Преображенский Ю.П., Преображенская Н.С., Львович И.Я. Некоторые аспекты информатизации образовательных учреждений и развития медиакомпетентности преподавателей и руководителей // Вестник Воронежского государственного технического университета. 2013. Т. 9. № 5-2. С. 134-136.

2. Преображенский Ю.П. О подготовке инженерных кадров // В сборнике: Современные инновации в науке и технике Сборник научных трудов 8-й Всероссийской научно-технической конференции с международным участием. Ответственный редактор А.А. Горохов. 2018. С. 175-179.

3. Преображенский Ю.П. Характеристики информационно-образовательного пространства вуза // В сборнике: Антропоцентрические науки: инновационный взгляд на образование и развитие личности Материалы VII Международной научно-практической конференции. 2018. С. 218-219.

4. Максимова И.В., Ваганова О.И., Карпова М.А. Использование видеофрагментов при преподавании дисциплин естественнонаучного цикла // Современные исследования социальных проблем (электронный научный журнал). 2018. Т. 9. № 9-2. С. 56-59.

5. Якушева С.Д. Самоменеджмент в деятельности педагога современного образовательного комплекса // Современные исследования социальных проблем (электронный научный журнал). 2018. Т. 9. № 11. C. 242-263.

\section{References}

1. Preobrazhenskij Yu.P., Preobrazhenskaya N.S., L'vovich I.YA. Nekotorye aspekty informatizacii obrazovatel'nyh uchrezhdenij i razvitiya mediakompetentnosti prepodavatelej i rukovoditelej // Vestnik Voronezhskogo gosudarstvennogo tekhnicheskogo universiteta. 2013. T. 9. № 5-2. S. 134-136.

2. Preobrazhenskij Yu.P. O podgotovke inzhenernyh kadrov // V sbornike: Sovremennye innovacii v nauke i tekhnike Sbornik nauchnyh trudov 8-j Vserossijskoj nauchno-tekhnicheskoj konferencii s mezhdunarodnym uchastiem. Otvetstvennyj redaktor A.A. Gorohov. 2018. S. 175-179. 
3. Preobrazhenskij Yu.P. Harakteristiki informacionno-obrazovatel'nogo prostranstva vuza // V sbornike: Antropocentricheskie nauki: innovacionnyj vzglyad na obrazovanie i razvitie lichnosti Materialy VII Mezhdunarodnoj nauchno-prakticheskoj konferencii. 2018. S. 218-219.

4. Maksimova I.V., Vaganova O.I., Karpova M.A. Ispol'zovanie videofragmentov pri prepodavanii disciplin estestvennonauchnogo cikla // Sovremennye issledovaniya social'nyh problem (elektronnyj nauchnyj zhurnal). 2018. T. 9. № 9-2. S. 56-59.

5. Yakusheva S.D. Samomenedzhment v deyatel'nosti pedagoga sovremennogo obrazovatel'nogo kompleksa // Sovremennye issledovaniya social'nyh problem (elektronnyj nauchnyj zhurnal). 2018. T. 9. № 11. S. 242-263. 